\title{
DIFFERENTIATION OF LOCAL HOUSING MARKETS IN THE POZNAŃ SUBURBAN AREA ${ }^{1}$
}

\author{
Justyna Tanaś, PhD \\ Department of Investment and Real Estate \\ Poznań University of Economics \\ e-mail: justyna.tanas@ue.poznan.pl
}

\begin{abstract}
In recent years, there has been a strong interest in land intended for single-family housing in the suburban zones of big cities. This is strongly related to the suburbanization process. In the present study, the author endeavored to present the differentiation of local markets of undeveloped real estate intended for single-family housing in the suburban zones of Poznań. Notary deeds related to sales transactions in the segment of undeveloped land plots were the basic source of information used in the article. The article shortly discusses the specifics of the land market in the suburban zone, presents the research method (the nature of the real estate prices index) and then, creates a regression function of plot prices and indicates hedonic prices for undeveloped plots intended for single-family housing in particular communes. Finally, it seeks to define the similarities and differences within the local undeveloped property market in the Poznań agglomeration.
\end{abstract}

Keywords: suburban area, local housing markets, market of land intended for single-family housing.

JEL Classification: R31.

Citation: Tanaś J., (2013), “Differentiation of Local Housing Markets in Poznań Suburban Area”, Real Estate Management and Valuation, vol. 21, no. 3, pp. 88-98.

DOI: $10.2478 /$ remav-2013-0030.

\section{Introduction}

The system transformation in Poland caused rapid development of the property market. An important segment of the property market is the market of land intended for single-family housing. During the last dozen years, there has been a growing interest in this segment. The market developed particularly in the suburban areas of big agglomerations. This was related to the intensification of people's migration from the centers of big cities and the development of housing in suburban areas.

In the study, the author endeavours to present the differentiation of the local market of undeveloped plots intended for single-family housing in the Poznań suburban area (17 communes within Poznań County). The analysis covers the period of 1995-2010.

Notarial deeds concerning sales transactions of undeveloped plots were the basic source of information used in the article. As a result of the long and thorough study of notarial deeds from the County Center of Land Surveying and Cartography Documentation in Poznań, a database was created encompassing sales transactions of undeveloped plots registered in Poznań during the period of 19952010. From the created database, transactions of plots intended for single-family housing were selected. Those transactions which unquestionably differed from market standards, i.e., the prices of which did not reflect market characteristics, were rejected. Plots with areas ranging from 300 to $3,000 \mathrm{~m}^{2}$ were considered as typical plots intended for housing. A total number of 27,335 transactions, which may be defined as characterized by a sufficient cohesion of market features so that they could

\footnotetext{
1 The project was financed by National Science Center
} 
form the basis for analysis of the formation of land prices within the local market of the Poznan agglomeration, were accepted for further analysis.

\section{Suburban area plot market}

One of the segments of the property market is building land (plots). The land market is a primary, natural segment of the property market. Land has been the subject of transactions for many years. Its supply includes not only undeveloped areas destined in spatial development planning for a specific type of building and placed on the market, but also areas the function of which may be changed or developed.

The land market is particularly unique in areas within the influence of big cities (suburban zones) (KRAJEWSKA 2010; GAWRON 2012). The strong urbanization of these areas and hence, the increased demand for land, causes differences between the customers' behavior patterns within this market segment and their behavior on the rural property market. We can conclude that, in suburban areas, it is such demand that creates space, the character of which is transformed from rural into other forms of use, that is more adequate for needs resulting from the current level of social and economic development. Generally, the market functions by the transformation of the land formerly used for agricultural purposes.

Suburban zones are affected by strong processes of spatial transformation which distinguishes them from other, typically rural, areas. Their specific character is connected with overlapping elements characteristic of urban and rural regions. Many researchers defined the suburban zone as a complex and urbanized space. The city centre strongly affects the transitional zone in the area of land use, making the land use more differentiated. The biggest differentiation of land use can be observed in areas located closest to the city; the further from its borders, the smaller its intensity, until the level is characteristic of rural areas. Areas formerly used for agricultural purposes are most often transformed into housing estates and areas of transportation. The value of a particular property grows along with its transformation and the price of plots depends on the location factor - the distance from the city and accessibility of a given area. The further away from the city a property is located, the less attractive and valuable it is in the opinion of investors.

A subject of significant interest is the market of undeveloped land intended for single-family housing in suburban areas. This is connected with the suburbanization phenomenon. This market is spontaneous, developing and differentiated.

It is by no means a uniform market but manifold due to such features as:

- differentiated physical and qualitative features of the property,

- availability of social infrastructure services,

- availability of transportation,

- location,

- possibilities and limitations of building on it.

\section{Nature of property price indexes}

The construction of indicators of changes in the prices of real estate creates problems both on the level of the very idea and at the moment of their practical application. The use of widely accepted methods for the calculation of price indexes of other goods or services is not possible due to the specifics of real estate as a good (WOOD 2005). The most often enlisted reasons behind such a situation are:

- the heterogeneity of real estate - there are no two identical pieces of real estate, flats, plots there is always a difference in at least one feature, e.g., location. Moreover, grasping the differences in the physical and geographical features in a given segment, in a given period creates a number of problems, mainly due to the quality of the database. Moreover, one must emphasize that the qualitative and quantitative features of real estate may undergo changes over time.

- price changeability - the observation of changes in the price of a given piece of real estate over time is extremely difficult and becomes evident at the moment of a sales transaction. One must emphasize that a couple of months may pass from the moment a transaction is made to the moment the information becomes available and can be used.

- the rarity of transactions - transactions on the real estate market, in relation to other goods, are made relatively rarely. 
Correct indexes, i.e., such which reflect changes of net price and are not biased by mistakes resulting from changes in the qualitative features, require such a system of criteria which allows for differences between groups of objects to be taken into account. In relation to real estate, this assumption seems difficult to realize. It imposes the necessity of properly preparing the primary data (CASE and WATCHER 2005). In addition to the quality of a given sample, the choice of the method used to evaluate similarities in this sample is a main element affecting the assessment of the suitability of a given measurement system.

Methods of building real estate price indexes, a criterion of which is the possibility of taking into account changes in the qualitative and quantitative features of real estate, can be divided into two groups: simple methods (based on the mean or median, which do not take into account such changes) and complex methods (hedonic regression methods, repeat sales, weighted average and hybrid ones, which account for the changes, at least in some part).

The use of each of these methods is burdened with certain limitations. The use of complex methods is often impossible because of the lack of a properly developed database containing information about the conditions of features of a particular piece of real estate. In the case of the occurrence of a small number of features describing a piece of real estate, the differences resulting from the use of complex and simple methods are of little importance. This is confirmed by numerous studies conducted in countries where the construction of price indexes on the real estate markets is well developed (TROJANEK 2012).

The imperfection of simple methods is sometimes minimized using complex ones, particularly hedonic regression. There have been many examples of the hedonic method used in real estate market research, however, its most important use seems to be in building real estate price indexes. The nature of the hedonic method comes down to the assumption that the price of a heterogenic good can be described using its features. In other words, the method may be used to determine the costliness of particular features of a given good. In order to define the influence of particular features on the value of a given good, econometric equations have been constructed where the explained variable is the price of a given good and the explanatory variables are its qualitative and quantitative features (TROJANEK 2013).

In hedonic methods, an important question is the choice of the form of the regression function. In the case of research on changes in prices on the real estate market, a log-linear form of the regression function is most often used in empirical research: :

$$
\log P=\beta_{0}+\sum_{i=1}^{K} \beta_{i} X_{i}+u
$$

There are a few reasons behind the choice of this form of the function (Malpezzi 2003). First of all, the log-linear model helps added value (e.g., connected with better location) to change proportionally with the area and other features of, e.g., the plot (in the case of the linear function, a better location will, for example, have the same influence on the value of a plot with an area of $300 \mathrm{~m}^{2}$, as that of $1,000 \mathrm{~m}^{2}$, while in the case of a log-linear function, the influence will be differentiated). Secondly, estimated regression coefficients are easy to interpret. The coefficient of a given variable may be interpreted as the percentage change of the value of a plot caused by the unit change of the price factor. Thirdly, a log-linear function often lessens problems connected with heteroscedasticity or the variance variable of a random component.

Hedonic regression ${ }^{2}$ is built mainly in two ways (BOURASSA, HOESLI and SUN 2006):

- on the basis of an equation of plot prices for each of the analyzed periods, or

- on the basis of an equation of plot prices for two or more periods.

The second approach, in which a regression equation of plot prices is constructed including the binary time variable, was used in the study. The equation can be described by the formula:

where:

$$
\log \left(p_{i}\right)=\beta_{0}+\sum_{\tau=1}^{T} \delta^{\tau} Q_{i}^{\tau}+\sum_{i=1}^{j} \beta_{j} X_{i j}+u_{i}
$$
2 An extensive discussion on hedonic methods and their division can be found in the works of TRIPLETT (2004), LI,
PRUD'HOMME, YU (2006), HILL and MELSER (2008), HILL (2010). 
$Q_{i}^{\tau}$ - the dummy variable (assumes the value of 1 if a given observation comes from period $\tau$, in other cases 0 ).

The adaptation of the hedonic method for research on price changes on the real estate market requires significant effort in collecting data, because information is necessary not only regarding the prices, but also about the states of features of each piece real estate. The lack of a sufficiently big database which includes trustworthy information related to the states of real estate prices may prevent the hedonic method from being a trustworthy indicator of plot prices in a definite time.

\section{Hedonic indexes of plot prices in the communes of Poznan County in 1995-2010}

The hedonic method was used in research on the changeability of plot prices in the communes of Poznan County in the period of 1995-2010. It was based on a regression equation which includes the binary variable of time (2). Econometric equations describing price changeability in the analyzed period were built for the analyzed communes. The choice of explanatory variables, both qualitative and quantitative, was limited by the information available in the database. In the research, the function of a log-linear model was used. The explanatory variables used in the study have been presented in table 1.

Table 1

Qualitative and quantitative variables used in the model

\begin{tabular}{|c|c|c|}
\hline Variable & Symbol & Description \\
\hline PERIOD & $\begin{array}{c}R 1-1996 . \\
\ldots . \\
R 16-2010 K W .\end{array}$ & $\begin{array}{l}16 \text { binary variables. When a transaction was entered in } \\
\text { the given period - } 1 \text {, in other cases - } 0 \text {. }\end{array}$ \\
\hline Area & Area & $\begin{array}{l}\text { Area of a given property expressed in } \\
\qquad 100 \mathrm{~m}^{2} .\end{array}$ \\
\hline $\begin{array}{l}\text { Distance } \\
\text { from the } \\
\text { center of } \\
\text { Poznań }\end{array}$ & $\overline{D P C}$ & $\begin{array}{l}\text { The distance of each plot from the center of Poznan } \\
\text { was measured, using the coordinates of plot centers } \\
\text { and the geographical coordinates of the center of } \\
\text { Poznan. The distance was measured in a straight line. }\end{array}$ \\
\hline $\begin{array}{l}\text { Distance } \\
\text { from the } \\
\text { center of a } \\
\text { commune }\end{array}$ & $\overline{D C C}$ & $\begin{array}{l}\text { The distance of each plot from the center of the main } \\
\text { town in a given commune was measured, using the } \\
\text { coordinates of the plot centers and the geographical } \\
\text { coordinates of a given town center. The distance was } \\
\text { measured in a straight line. }\end{array}$ \\
\hline
\end{tabular}

Source: author's own research.

Next, using GRETL software, an econometric equation in the form of equation (2) was estimated for all of the analyzed communes during 1995-2010, in which the explained variable was the price

of $1 \mathrm{~m}^{2}$ of a plot, and the explanatory variables were the year of the transaction, the area of a plot, the distance of a plot from the center of Poznań and the distance from the center of the main town in a given commune (the distances were measured using the exact geographical location of the center of each plot). In tables $2 a$ and $2 b$, the author presents the results of the regression function for all communes.

Table 2a

Results of the regression function for the communes of Poznan County in 1995-2010

\begin{tabular}{|c|c|c|c|c|c|c|c|c|c|}
\hline & Buk & Czerwonak & Dopiewo & Kleszczewo & Komorniki & Kórnik & Kostrzyn & Luboń & Mosina \\
\hline constant & 7.089 & 2.700 & 2.239 & 3.423 & 4.227 & 3.387 & 3.468 & 2.900 & 3.406 \\
\hline area & -0.040 & -0.030 & -0.015 & -0.026 & -0.015 & -0.021 & -0.019 & -0.032 & -0.017 \\
\hline DCC & -0.191 & -0.044 & 0.052 & 0.023 & -0.055 & -0.046 & -0.051 & -0.178 & -0.070 \\
\hline DPC & -0.164 & -0.030 & -0.042 & -0.088 & -0.148 & -0.055 & -0.068 & 0.029 & -0.061 \\
\hline DYear_2 & 0.216 & 0.151 & 0.579 & 0.232 & 0.247 & 0.161 & 0.464 & 0.019 & 0.415 \\
\hline DYear_3 & 0.570 & 0.891 & 1.180 & 0.476 & 0.486 & 0.393 & 0.909 & 0.564 & 0.678 \\
\hline DYear_4 & 0.780 & 1.293 & 1.597 & 0.902 & 1.048 & 1.163 & 1.133 & 1.096 & 1.318 \\
\hline DYear_5 & 1.224 & 1.596 & 1.838 & 0.877 & 1.091 & 1.452 & 1.265 & 1.370 & 1.546 \\
\hline DYear_6 & 1.305 & 1.669 & 2.062 & 1.183 & 1.393 & 1.622 & 1.401 & 1.492 & 1.684 \\
\hline DYear_7 & 1.596 & 1.776 & 2.002 & 1.256 & 1.143 & 1.559 & 1.408 & 1.610 & 1.781 \\
\hline DYear_8 & 1.636 & 1.656 & 1.934 & 1.253 & 1.476 & 1.391 & 1.267 & 1.566 & 1.671 \\
\hline DYear_9 & 1.393 & 1.794 & 1.990 & 1.230 & 1.648 & 1.376 & 1.299 & 1.891 & 1.766 \\
\hline
\end{tabular}




\begin{tabular}{cccccccccc}
\hline DYear_10 & 1.501 & 1.922 & 2.053 & 1.433 & 1.753 & 1.569 & 1.496 & 1.766 & 1.857 \\
\hline DYear_11 & 1.505 & 2.095 & 2.147 & 1.654 & 1.881 & 1.654 & 1.669 & 1.714 & 1.933 \\
\hline DYear_12 & 1.542 & 2.369 & 2.334 & 1.860 & 2.109 & 1.833 & 2.074 & 2.102 & 2.061 \\
\hline DYear_13 & 1.976 & 2.864 & 3.003 & 2.540 & 2.549 & 2.428 & 2.570 & 2.547 & 2.668 \\
\hline DYear_14 & 2.366 & 3.419 & 3.480 & 3.019 & 2.977 & 2.999 & 3.006 & 2.885 & 3.045 \\
\hline DYear_15 & 2.322 & 3.394 & 3.409 & 3.084 & 2.982 & 2.975 & 3.020 & 2.803 & 3.084 \\
\hline DYear_16 & 2.292 & 3.360 & 3.451 & 3.000 & 3.047 & 2.994 & 3.027 & 2.841 & 2.990 \\
\hline R2 coefficient & 0.862 & 0.885 & 0.806 & 0.890 & 0.840 & 0.772 & 0.882 & 0.935 & 0.842 \\
\hline Standard error of residuals & 1.933 & 2.059 & 1.954 & 1.991 & 1.880 & 1.959 & 1.900 & 1.909 & 2.058 \\
\hline R2 after correction & 0.855 & 0.883 & 0.804 & 0.886 & 0.836 & 0.770 & 0.879 & 0.931 & 0.839 \\
\hline
\end{tabular}

Source: author's own research on the basis of data collected from the County Center of Land Surveying and Cartography Documentation (PODGiK) in Poznań.

Table 2b

Results of the regression function for the communes of Poznań County in 1995-2010

\begin{tabular}{|c|c|c|c|c|c|c|c|c|}
\hline & $\begin{array}{c}\text { Murowana } \\
\text { Goślina }\end{array}$ & Pobiedziska & Puszczykowo & Rokietnica & Stęszew & $\begin{array}{c}\text { Suchy } \\
\text { Las }\end{array}$ & Swarzędz & $\begin{array}{l}\text { Tarnowo } \\
\text { Podgórne } \\
\end{array}$ \\
\hline constant & 1.922 & 3.492 & 4.642 & 3.539 & 3.085 & 3.092 & 3.514 & 3.804 \\
\hline area & -0.023 & -0.043 & -0.013 & -0.023 & -0.002 & -0.020 & -0.030 & -0.014 \\
\hline DCC & -0.027 & & 0.101 & -0.018 & -0.059 & -0.128 & -0.040 & -0.022 \\
\hline DPC & & -0.059 & -0.143 & -0.078 & -0.048 & & -0.085 & -0.094 \\
\hline DYear_2 & 0.339 & 0.305 & 0.433 & 0.370 & 0.090 & 0.362 & 0.211 & 0.555 \\
\hline DYear_3 & 0.560 & 0.511 & 1.112 & 0.577 & 0.393 & 0.763 & 0.809 & 1.034 \\
\hline DYear_4 & 0.718 & 0.819 & 1.292 & 0.914 & 0.703 & 1.166 & 0.942 & 1.205 \\
\hline DYear_5 & 1.242 & 1.300 & 1.545 & 1.384 & 1.155 & 1.638 & 1.342 & 1.685 \\
\hline DYear_6 & 1.473 & 1.370 & 1.724 & 1.657 & 1.119 & 1.726 & 1.365 & 1.929 \\
\hline DYear_7 & 1.532 & 1.437 & 1.824 & 1.538 & 1.327 & 1.746 & 1.485 & 1.856 \\
\hline DYear_8 & 1.571 & 1.351 & 1.782 & 1.511 & 1.196 & 1.596 & 1.572 & 1.790 \\
\hline DYear_9 & 1.471 & 1.451 & 1.973 & 1.644 & 1.433 & 1.679 & 1.680 & 1.913 \\
\hline DYear_10 & 1.585 & 1.510 & 1.697 & 1.724 & 1.417 & 1.905 & 1.789 & 2.023 \\
\hline DYear_11 & 1.783 & 1.793 & 2.061 & 1.780 & 1.498 & 1.956 & 1.945 & 2.129 \\
\hline DYear_12 & 1.960 & 1.987 & 2.382 & 2.034 & 1.841 & 2.185 & 2.150 & 2.182 \\
\hline DYear_13 & 2.654 & 2.416 & 3.062 & 2.591 & 2.228 & 2.765 & 2.752 & 2.705 \\
\hline DYear_14 & 2.976 & 2.911 & 2.981 & 3.065 & 2.697 & 3.243 & 3.183 & 3.168 \\
\hline DYear_15 & 2.988 & 2.904 & 2.978 & 3.027 & 2.796 & 3.213 & 3.163 & 3.177 \\
\hline DYear_16 & 2.927 & 2.905 & 3.021 & 3.086 & 2.787 & 3.253 & 3.214 & 3.202 \\
\hline R2 coefficient & 0.789 & 0.768 & 0.850 & 0.767 & 0.795 & 0.880 & 0.848 & 0.755 \\
\hline Standard error of residuals & 2.192 & 2.182 & 1.954 & 1.938 & 2.215 & 2.005 & 1.958 & 2.142 \\
\hline R2 after correction & 0.784 & 0.765 & 0.843 & 0.765 & 0.792 & 0.879 & 0.847 & 0.753 \\
\hline
\end{tabular}

Source: author's own research on the basis of data collected from the PODGiK in Poznań.

On the basis of the obtained results, we can conclude that the explanatory variables used in the equations explain the formation of the plot prices in the communes of Poznan County during the period of $1995-2010$ in around $80 \%$. Moreover, the vast majority of the variables used in the model turned out to be statistically significant.

After appropriate transformation ${ }^{3}$, the regression coefficients of the explanatory variables provide interesting information. Table 3 comprises the sensitivity of the price of $1 \mathrm{~m}^{2}$ to an increase in the distance of a plot from the center of Poznań in the particular communes of Poznań County.

Table 3

Sensitivity of the price of $1 \mathrm{~m}^{2}$ to an increase in the distance of a plot from the center of Poznan in the particular communes of Poznań County

\begin{tabular}{lc}
\hline Commune & $\begin{array}{c}\text { Sensitivity of the price of } 1 \mathrm{~m}^{2} \text { to an increase in the distance of } \\
\text { a plot from the center of Poznań (ceteris paribus) }\end{array}$ \\
\hline Luboń & $2.90 \%$ \\
\hline Czerwonak & $-2.95 \%$ \\
\hline Dopiewo & $-4.12 \%$ \\
\hline Stęszew & $-4.71 \%$ \\
\hline Kórnik & $-5.34 \%$ \\
\hline Pobiedziska & $-5.73 \%$ \\
\hline Mosina & $-5.88 \%$ \\
\hline Kostrzyn & $-6.58 \%$ \\
\hline
\end{tabular}

\footnotetext{
${ }^{3}$ Using the log-linear function for the interpretation of regression coefficients requires the following transformation: $\exp (\mathrm{x})-1$ 


\begin{tabular}{ll}
\hline Rokietnica & $-7.52 \%$ \\
\hline Swarzędz & $-8.15 \%$ \\
\hline Kleszczewo & $-8.39 \%$ \\
\hline Tarnowo Podgórne & $-9.00 \%$ \\
\hline Puszczykowo & $-13.34 \%$ \\
\hline Komorniki & $-13.76 \%$ \\
\hline Buk & $-15.12 \%$ \\
\hline
\end{tabular}

Source: author's own research on the basis of data collected from the PODGiK in Poznan.

In the majority of the communes, an increase in the distance from the center of Poznan caused a decrease in the price of $1 \mathrm{~m}^{2}$. The biggest sensitivity was found in the case of the Buk commune, where a $1 \mathrm{~km}$ increase in the distance from the center of Poznan resulted in the decrease of the price of $1 \mathrm{~m}^{2}$ by $15 \%$. In one commune - Lubon, a $1 \mathrm{~km}$ increase in the distance from the center of Poznan resulted in a $2.9 \%$ increase of the price of $1 \mathrm{~m}^{2}$ of a plot. From the statistical point of view, the distance of the plots from the center of Poznań was not significant in the communes of Murowana Goślina and Suchy Las.

Table 4 depicts the sensitivity of the price of $1 \mathrm{~m}^{2}$ to an increase in the distance of the plot from the center of the main town in a given commune.

Table 4

Sensitivity of the price of $1 \mathrm{~m}^{2}$ to an increase in the distance of a plot from the center of the main town in a given commune of Poznań County

\begin{tabular}{lc}
\hline Commune & $\begin{array}{c}\text { Sensitivity of the price of } 1 \mathrm{~m}^{2} \text { to an increase in the distance of a } \\
\text { plot from the center of the main town in a given commune (ceteris } \\
\text { paribus) }\end{array}$ \\
\hline Puszczykowo & $10.60 \%$ \\
\hline Dopiewo & $5.34 \%$ \\
\hline Kleszczewo & $2.35 \%$ \\
\hline Rokietnica & $-1.78 \%$ \\
\hline Tarnowo Podgórne & $-2.13 \%$ \\
\hline Murowana Goślina & $-2.65 \%$ \\
\hline Swarzędz & $-3.92 \%$ \\
\hline Czerwonak & $-4.29 \%$ \\
\hline Kórnik & $-4.47 \%$ \\
\hline Kostrzyn & $-4.96 \%$ \\
\hline Komorniki & $-5.35 \%$ \\
\hline Stęszew & $-5.69 \%$ \\
\hline Sosina & $-6.80 \%$ \\
\hline Luboń Las & $-11.99 \%$ \\
\hline Buk & $-16.29 \%$ \\
\hline
\end{tabular}

Source: as in table 3.

In the case of the vast majority of communes, an increase in the distance from the center of the main town in a given commune resulted in a decrease in the price of $1 \mathrm{~m}^{2}$. The biggest sensitivity was noticed in the Buk commune, where an increase in the distance from the center of Buk by $1 \mathrm{~km}$ caused the price of $1 \mathrm{~m}^{2}$ to decrease by $17 \%$. In the case of Puszczykowo, Dopiewo and Kleszczewo communes, a $1 \mathrm{~km}$ increase in the distance from the centers of the main towns of those communes resulted in an increase in the price of $1 \mathrm{~m}^{2}$ of a plot ranging from $2 \%$ to around $11 \%$. From the statistical point of view, the distance of the plots from the center of the main town in the Pobiedziska commune was not found to be important. 


\section{Differentiation of local undeveloped properties in the Poznań suburban zone}

The property market is considered a local market and therefore, changes occurring in many areas, however similar, differ from one another. Changes in the level of plot prices frequently show significant differences. There are two reasons for such a situation (Meen 1996):

- the different behavior of economic factors affecting property prices - for example, household income in different regions of the country may be characterized by various growth rates, particularly in a short time,

- the different reaction of housing prices in particular regions to general changes of their economic determinants. This is mainly the result of the differences in the structure of property markets in different areas.

Due to the above mentioned reasons, the author strived to determine the similarities and differences between markets in the communes of Poznań County in 1995-2010. Poznań County has been presented in fig. 1. On the basis of the developed plot price indexes, using hedonic regression we can conclude that, in the period of 1995-2004, the biggest price increase in most communes took place in 1999. A phenomenon of similar intensity occurred also a year earlier, though only in the communes of Komorniki, Kórnik, Luboń and Mosina. During 2004-2010, the prices increased most in 2006, 2007 and 2008. In the communes of Kleszczewo, Kostrzyn, Czerwonak, Kórnik, Swarzędz, Dopiewo and Pobiedziska, the prices during the last six years of the analysis increased in the nominal approach by more than $400 \%$. However, it should be noted that the course of the price indexes for the individual communes was similar. In 1995-2010, we can distinguish certain periods which were characteristic for most of the communes:

- 1995-2000 - period of a price increase,

- 2001-2002 - period of a price decrease,

- 2003-2008 - period of a price increase (especially strong in 2006-2008),

- 2009 - period of a moderate price increase.

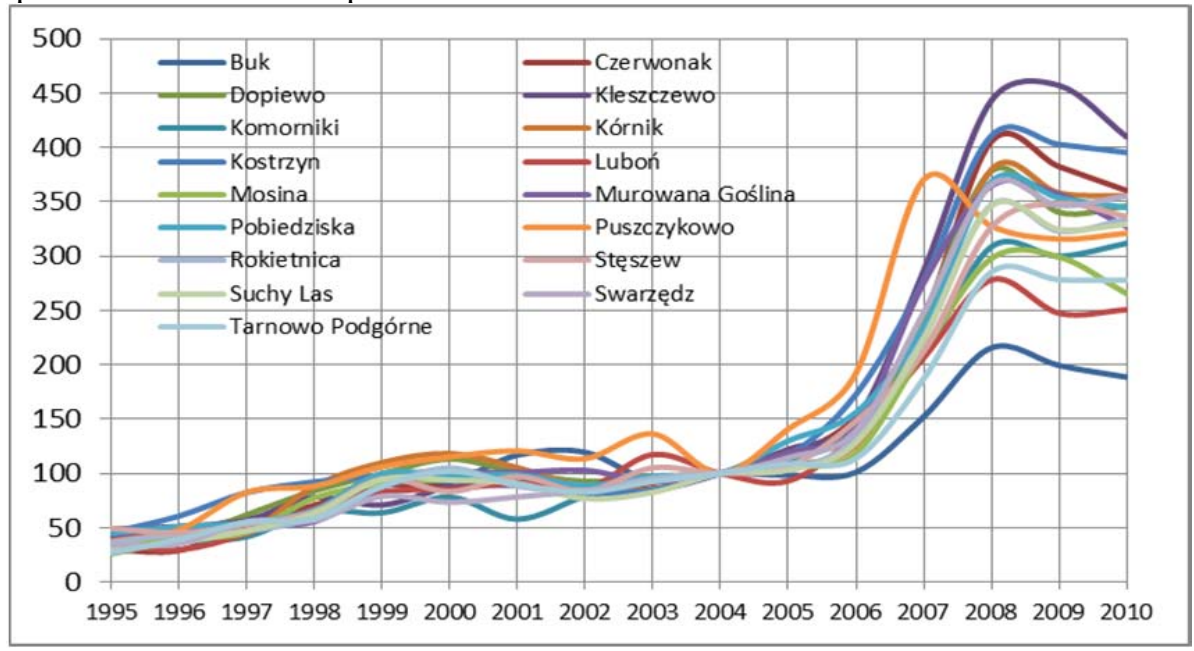

Fig. 1. Real price indexes of undeveloped plots intended for single-family housing in the communes of Poznań County in 1995-2010 (year $2004=100$, constant prices from 2004). Source: as in table 3.

The intervals which were distinguished above relate to most of the communes (the described changes in prices did not occur in exactly the same years in every commune - there was a shift in time). The distinguished time intervals of price changes in the communes of Poznań County to a large extent overlap the upward and downward business cycle periods in Poland. This fact coincides with other research in which it was concluded that a cycle on the property market reacts to key elements of the economy but is not a simple reflection of the business cycle of a given country.

Figures 2, 3 and 4, present the hedonic prices of $1 \mathrm{~m}^{2}$ for undeveloped plots intended for singlefamily housing in the communes of Poznan County compared to prices in the county during 1995-2010. The communes were grouped assuming the level of prices in relation to the prices in Poznań County as a criterion.

Figure 2 depicts those communes which were characterized by higher levels of hedonic prices than the same prices within the whole county. In the whole analyzed period, the highest prices (therefore, those differing most from the prices in the county) were reached by plots in the urban communes of 
Lubon and Puszczykowo. Since 2000, prices have started to differ significantly in the communes of Suchy Las and Tarnowo Podgórne. In other communes (i.e., Dopiewo, Komorniki and Swarzędz), only in 2007 was there a more rapid price increase than in Poznan County. An upward trend was observed in the last year of the analysis for all of the communes included in the graph. It should be noted that this group includes mainly communes located close to Poznan, in which suburbanisation processes were most advanced.

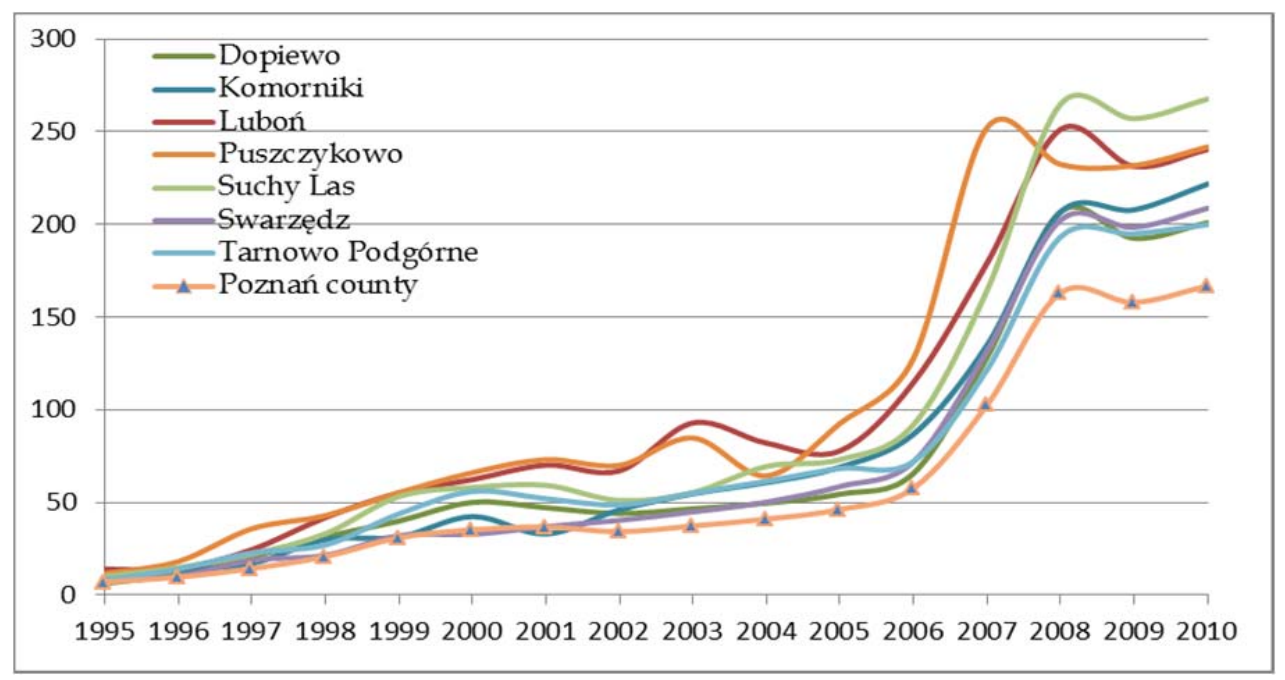

Fig. 2. Hedonic prices of $1 \mathrm{~m}^{2}$ of undeveloped plots intended for single-family housing in selected communes of Poznań County in relation to prices in the county in 1995-2010. Source: as in table 3.

In the whole analyzed period, the highest prices (therefore differing most from the prices in the county) were reached by plots in the urban communes of Lubon and Puszczykowo. Since 2000, prices have started to differ significantly in Suchy Las and Tarnowo Podgórne communes. In other communes (i.e., Dopiewo, Komorniki and Swarzędz), only in 2007 was there a more rapid price increase than in the county. In all of the communes included in the graph, there was upward trend in the last year of the analysis. One should note that all of the mentioned communes are located close to Poznań, where suburbanisation processes were most advanced.

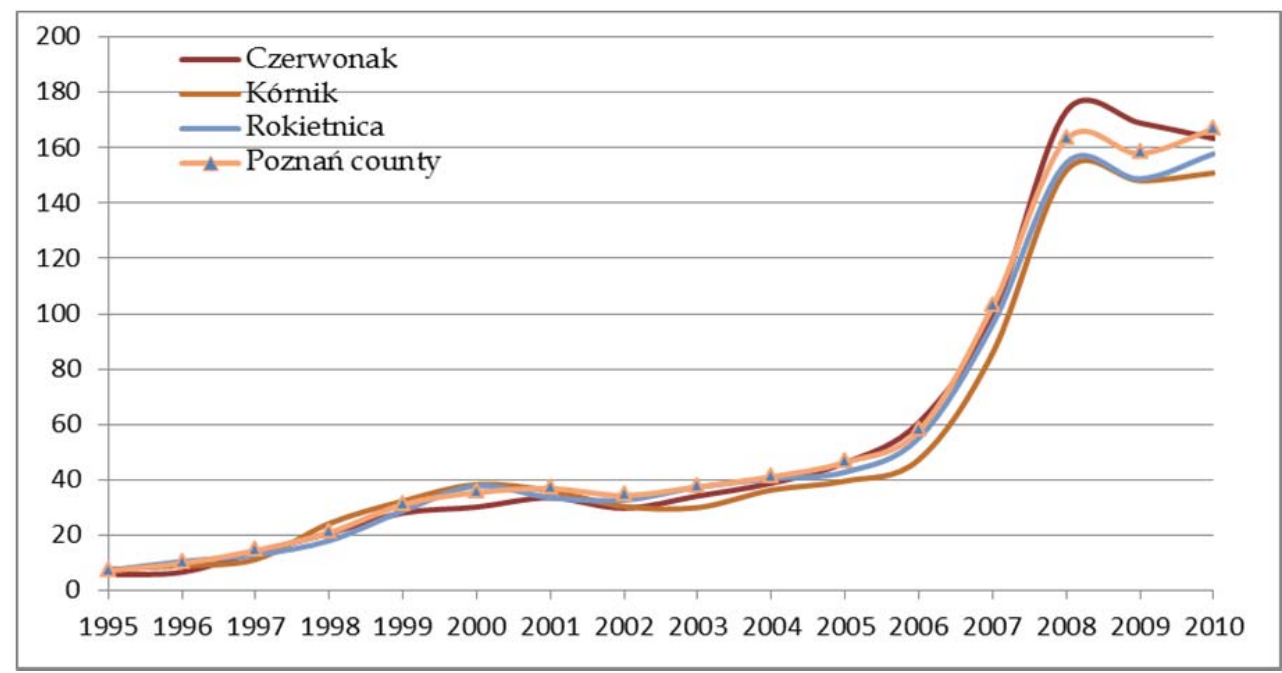

Fig. 3. Hedonic prices of $1 \mathrm{~m}^{2}$ of undeveloped plots intended for single-family housing in selected communes of Poznań County in relation to prices in the county in 1995-2010. Source: as in table 3.

Figure 3 encompasses communes in which prices were at a level similar to that of prices on the county scale, that is Rokietnica, Kórnik and Czerwonak communes. Though land prices in Czerwonak commune were slightly lower than prices in the whole county until 2004, they have generally been at a slightly higher level than in Poznań County since 2005. Land prices in Kórnik commune fluctuated and were either somewhat higher or lower than the prices in the whole county until 2000, but have 
consistently been slightly lower since 2001. A similar trend was observed in Rokietnica commune. In all three of the communes, prices increased except for the years 2001, 2002 and 2009, when there was a fall in prices in comparison to the previous year.

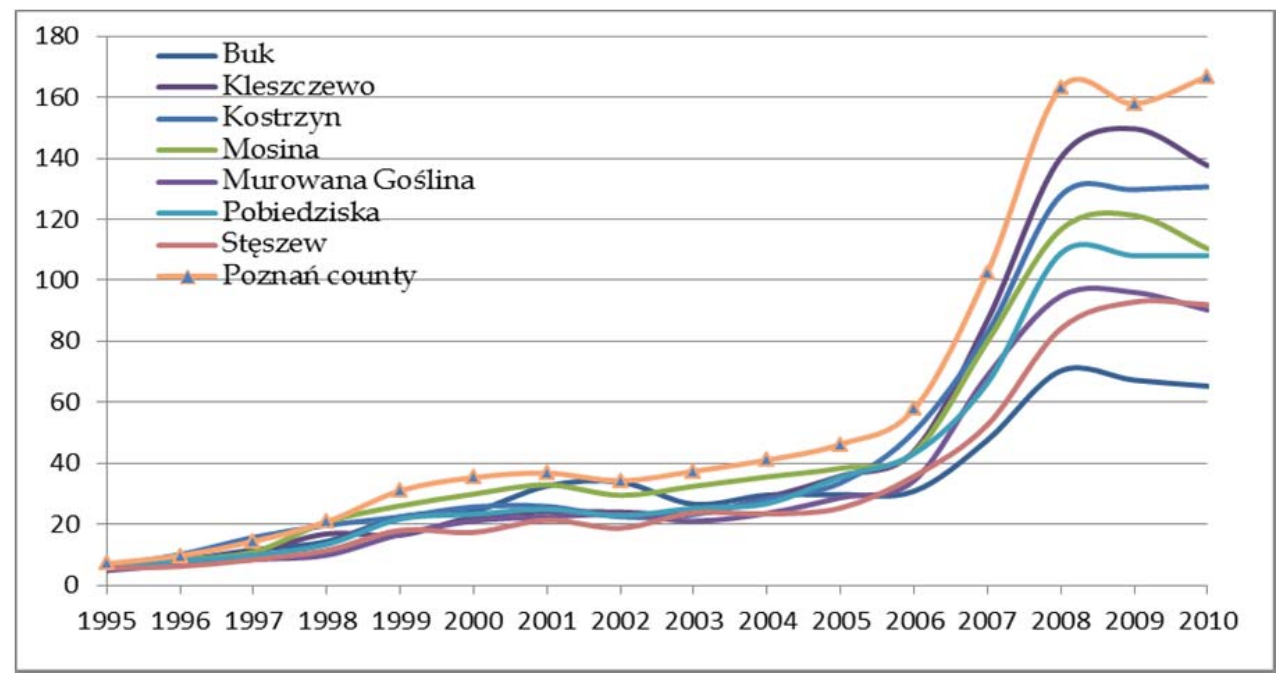

Fig. 4. Hedonic prices of $1 \mathrm{~m}^{2}$ of undeveloped land intended for single-family housing in selected communes of Poznań County in relation to prices in the county in 1995-2010. Source: as in table 3.

Figure 4 comprises communes in which prices were at a lower level than prices in the whole county (during the entire analyzed period). Among these communes are basically those of the so called "second ring", i.e., more distant from Poznań: Buk, Kostrzyn, Murowana Goślina, Stęszew, Pobiedziska, Mosina and Kleszczewo. Until 2006, the prices in these particular communes did not differ significantly from each other. Only since 2006 could a gradual differentiation of prices in these communes be observed, (though they all remained lower than prices for the whole county. The biggest increase in prices in the discussed regions took place in communes located in the direct proximity of Poznań, i.e., Mosina, Kleszczewo and Kostrzyn. The smallest increase in prices occurred in Buk, Stęszew and Murowana Goślina. In all of the communes presented in this graph (with the exception of Kostrzyn and Pobiedziska), the prices fell in the last year of the analysis.

In the following figures (5 and 6), the author has presented maps depicting the prices of land intended for single-family housing in Poznań County in 2000 and 2010.

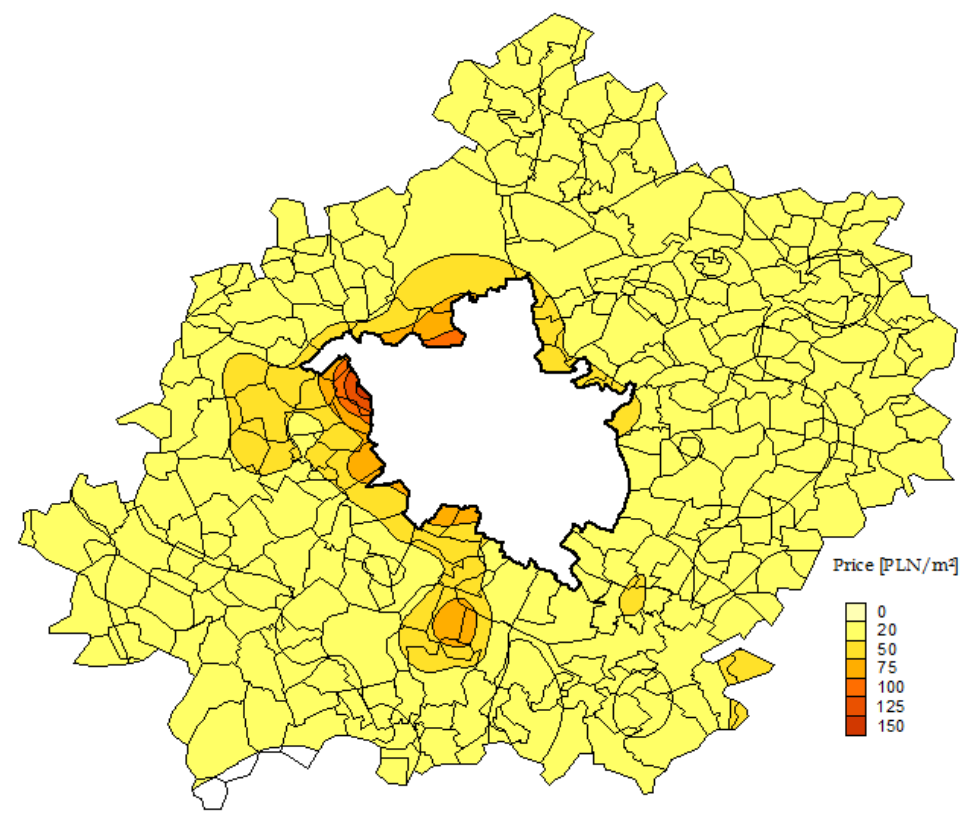

Fig. 5. Map depicting prices of land intended for single-family housing in Poznań County in 2000. Source: as in Table 3. 


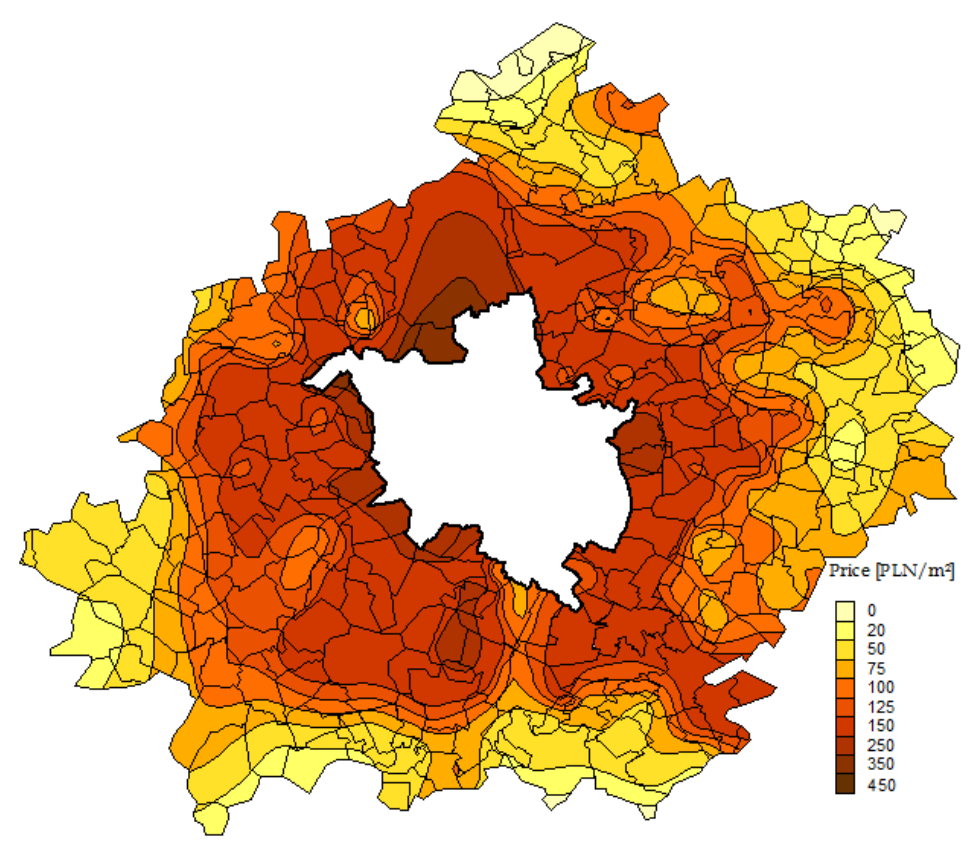

Fig. 6. Map depicting prices of land intended for single-family housing in Poznań County in 2010. Source: as in Table 3.

On the basis of the collected data, the author established the average prices for 153 precincts (out of a total of 283) in 2000. In the vast majority of the precincts (more than $80 \%$, i.e., in 126 precincts) there was a domination of prices below $20 \mathrm{PLN} / \mathrm{m}^{2}$. The lowest average prices were in Stęszew, Komorniki and Mosina. The highest prices for $1 \mathrm{~m}^{2}$ were noted in the case of plots located in Baranowo (nearly $160 \mathrm{PLN} / \mathrm{m}^{2}$ ) and Przeźmierowo (more than $113 \mathrm{PLN} / \mathrm{m}^{2}$ ), as well as those located in Tarnowo Podgórne and Suchy Las communes (nearly $100 \mathrm{PLN} / \mathrm{m}^{2}$ ). High prices also characterized plots in Puszczykowo (around $91 \mathrm{PLN} / \mathrm{m}^{2}$ ), Skórzewo (89 PLN/m², Dopiewo commune), Żabikowo (77 $\mathrm{PLN} / \mathrm{m}^{2}$, Luboń commune), and Swadzim and Wysogotowo (around 75 PLN/m² Tarnowo Podgórne commune).

In 2010, one could note a significant increase in the average prices of $1 \mathrm{~m}^{2}$ of land in the analyzed communes. Average prices were determined for 201 precincts. In a small number of precincts (i.e., 9 , which accounted for $10 \%$ of their total number) the average price of $1 \mathrm{~m}^{2}$ was lower than 50 PLN, but in the significant majority of the precincts, prices oscillated above this level. Maximum levels of prices for $1 \mathrm{~m}^{2}$ were noted in Suchy Las and Tarnowo Podgórne communes, with minimum levels in Buk, Kostrzyn and Murowana Goślina communes. The highest prices were reached in the case of properties located in: Suchy Las, Złotniki, and Biedrusko (419, 372 and $317 \mathrm{PLN} / \mathrm{m}^{2}$ respectively, Suchy Las commune), Chyby, Baranowo and Przeźmierowo (366, 339 and $328 \mathrm{PLN} / \mathrm{m}^{2}$ respectively, Tarnowo Podgórne commune), Zalasewo, Swarzędz and Bogucin (315, 293 and $239 \mathrm{PLN} / \mathrm{m}^{2}$ respectively, Swarzędz commune), Skórzewo and Dąbrówka (310 and $267 \mathrm{PLN} / \mathrm{m}^{2}$ respectively, Dopiewo commune), Puszczykowo and Niwka (299 and $240 \mathrm{PLN} / \mathrm{m}^{2}$ respectively, Puszczykowo commune); Żabikowo and Luboń (283 and $238 \mathrm{PLN} / \mathrm{m}^{2}$ respectively, Luboń commune), and Plewiska, Łęczyca and Komorniki (281, 254 and $241 \mathrm{PLN} / \mathrm{m}^{2}$ respectively, Komorniki commune). The lowest average prices were noted in the precincts of Łoskoń Stary and Białężyn (29 and $39 \mathrm{PLN} / \mathrm{m}^{2}$ respectively, Murowana Goślina commune), Szewce and Dakowy (29 and $41 \mathrm{PLN} / \mathrm{m}^{2}$ respectively, Buk commune), Libartowo (36 PLN/m², Kostrzyn commune), and Węglewo (38 PLN/m², Pobiedziska commune).

\section{Conclusion}

In the above described study, the author endeavoured to present the differentiation in the development of the local undeveloped property market intended for single-family housing in the Poznań suburban zone. This differentiation was reflected both in the scale of land trade in the particular communes and in the changes of prices. 
The analysis of hedonic prices of undeveloped property intended for single-family housing allows us to state that a more than average price was characteristic mainly of precincts located close to Poznań, especially along the western border of the city (Dopiewo, Tarnowo Podgórne, and Rokietnica communes). This is, among others, the result of the traditional perception of the western part of the city as the most favourable for the development of housing functions. In addition to this, two concentrations of relatively high land prices developed in the southern part of Poznań County (with the first one including Puszczykowo and some precincts of Komorniki commune and the other extending south-east of Poznań and covering some precincts of Kórnik commune).

Observing the development of the market in the suburban zones of many cities, its uniform development often goes unnoticed. Most often, we note a high concentration of transactions in some towns, usually located close to the central city and along transport routes. Moreover, although the scale of turnover shows a decreasing trend along with an increase in the distance from the centre, the process is not stable and undergoes changes. The market of building plots in the suburban zones of Poznań has been developing dynamically. This is confirmed, among others, by the processes of development in European cities. One must remember that this market may positively influence the development of other complementary local markets (e.g., the development of housing, the location of businesses not related to agriculture, the transformation of the countryside structure). Therefore, it should be treated as a significant factor of the social and economic development of smaller towns in suburban areas.

\section{Reference}

Bourassa, S.C., HoesLi, M., Sun, J., 2006, A Simple Alternative House Price Index Method, Journal of Housing Economics, vol. 15, s. 80-97.

CASE, B., WACHTER, S., 2005, Residential Real Estate Price Indices as Financial Soundness Indicators: Methodological Issues, BIS Paper, no 21, s. 197-211.

GAWRON, H., 2012, Wptyw cech fizycznych działek na ceny gruntów budowlanych w aglomeracji miejskiej (na przykładzie aglomeracji poznańskiej), in: ŹRÓBEK, S., (red.), Studia i materiały Towarzystwa Naukowego Nieruchomości, Volume 20, Number 2, Olsztyn, s. 47-58.

KRAJEWSKA, M., 2010, Analiza zmian wartości gruntów w strefach podmiejskich dużych miast, in: ŹRÓBEK, S., (red.), Studia i materiały Towarzystwa Naukowego Nieruchomości, Volume 18, Number 3, Olsztyn, s. 51-60.

MalPezZI, S. (2003), Hedonic Pricing Models: A Selective and Applied Review, in: T. O'Sullivan, K. GiBB (red.) Housing Economics and Public Policy: Essays in honor of Duncan Maclennan, red., Oxford: Blackwell.

MeEn, G., 1996, Modelling Spatial Housing Markets. Theory, Analysis and Policy, Kluwer Academic Publishers, USA.

TrojANEK, R., 2012, An analysis of changes in dwelling prices in the biggest cities of Poland in 2008-2012 conducted with the application of the hedonic method, in: Actual Problems of Economics $2012 \mathrm{nr} 7$ Kijów: National Academy of Management. s. 5-14.

TROJANEK, R., 2013, Fluctuations of dwellings' prices in the biggest cities in Poland during 1996-2011, in: Actual Problems of Economics 2013 , vol. 2 - Kijów: National Academy of Management. s. 224-231.

WooD, R., 2005, A Comparision of UK Residential House Price Indices, BIS Paper 2005, nr 21, s. 212-227. 